\title{
THE ACTION OF CAFFEINE UPON THE GERMINATION AND GROWTH OF SEEDS
}

\author{
By FRED RANSOM, M.D., ED., Beit Research Fellow. \\ From the Pharmacological Laboratory, Cambridge \\ (Second Communication) \\ (Received January 17th, 1912)
}

In the following communication an endeavour is made to throw light upon the function which caffeine exercises in plant economy. At present the reason for the storage of cafteine in certain parts of some plants is quite as unexplained as is the appearance of its allies, xanthine and hypoxanthine, in animal tissues. On the other hand, the fact that it is found chiefly in the seeds and in young and growing shoots suggests that it may have something to do with germination or with growth.

In a previous paper $I$ have shown that 1 per cent. solution of caffeine has a marked effect in delaying or preventing germination in a considerable variety of seeds. The following experiments unreservedly confirm those results. There was, however, the possibility that by treating seeds with very dilute solutions of caffeine a stimulating effect might be produced on germination or on growth or on both. The settlement of this point was one object of the present investigation.

The method adopted was the following:-On the bottom of glass needle boxes a thin layer of absorbent cotton-wool was placed, over this a piece of fine muslin was laid and the whole moistened with 50 c.c. of caffeine solution or tapwater. The seeds were then scattered thinly upon the muslin. The needle glasses were closed with loosely-fitting glass lids and stood either in the laboratory at about $17^{\circ} \mathrm{C}$. or in a thermostat regulated to $22^{\circ} \mathrm{C}$. Usually a series of glasses were charged with caffeine solutions of varying strength, with tapwater controls. At certain intervals the growths were compared by examination with the eye and, finally, the seedlings were carefully removed, either with or without the ungerminated seeds, superficially dried on blotting paper and weighed at once.

As regards germination it was found that caffeine solutions of $1 \cdot 0,0 \cdot 1,0.01$ per cent. caused very distinct delay. With 0.001 per cent. that was not so obvious, and seeds sown in 0.0001 per cent. germinated as quickly as the tapwater controls (Table I).

Besides delay, the stronger caffeine solutions had a very marked 
inhibitory effect, so that of the seeds sown in $1.0,0.1$, and 0.01 per cent. fewer germinated than in the weaker solutions or in tapwater (Table II).

Very dilute solutions of caffeine, 0.0001 per cent. and less, were without any cbvious effect at all, either on germination or on growth: As will be seen from the table, 0.001 per cent. appears to have a slight effect in hindering growth (Table III).

The effect of caffeine in solutions of about 0.01 per cent. or more, was such that the seedlings, weighed after two or three days' growth, were distinctly lighter than the tapwater controls (Table IV). In most of the following tables the same effect can be observed.

It being thus evident that caffeine added to tapwater does not stimulate germination or growth; further experiments were made to ascertain whether a different effect would follow when a salt or other substance was added to the caffeine solution.

Nitrate of Potash-Saccharose. (All solutions in tap water)

Cress $0.5 \mathrm{~g}$. in each glass and 50 c.c. fluid. Sown on 6/12/1911, Room temperature Medium

Condition on $8 / 12 / 1911$

Condition on 9/12/1911

(1) $\mathrm{KNO}_{3} 0.05 \%$

.. 1 and 4 are the best

Relatively about the

Weight on

$12 / 12 / 1911$

(2) $\mathrm{KNO}_{3} \mathbf{0 . 0 5} \%$

$\ldots 2$ and 3 about equal
$\ldots \quad$ but smaller than same

2.620

(3) Caffeine 0.01\% $\% \quad \ldots$ the others

2.385

(4) Tap water ... .., ... (5) Saccharose $2 \% \quad \ldots \quad \ldots 5$ and 6 are about

(6) Saccharose $2 \%$ than 4

6 is smaller than 5 . Both are less than 4

\begin{tabular}{|c|c|}
\hline & 2.590 \\
\hline & $2 \cdot 830$ \\
\hline $\begin{array}{c}6 \text { is smaller than } 5 . \\
\text { Both are less } \\
\text { than } 4\end{array}$ & $2 \cdot 620$ \\
\hline
\end{tabular}

The table shows very distinctly the influence of caffeine in retarding growth, but there was no stimulation.

Dextrose. (All solutions in tap water)

Mustard 1.0 g. seed in each glass and 50 c.c. fluid. Sown on 12/12/1911. Room temporature

Medium
(1) Dextrose $0.8 \%$

Condition on $14 / 12 / 1911$

Weight on $16 / 12 / 1911$

(1)

(2) Dextrose $0.2 \% \quad \ldots \quad \ldots$

(3) Dextrose $0.8 \% \quad \ldots \quad \ldots 1$ and 3 are the smallest $\quad 3.040$ Caffeine 0.001 \% $\ldots . . .$.

(4) Dextrose $0.2 \%, \ldots \quad \ldots 2$ and 4 are about equal $\quad \mathbf{3 . 6 7 0}$

$\begin{array}{llll}\text { (5) Tap water } \ldots & \ldots & \ldots & \\ & \ldots & \mathbf{4} & \end{array}$

(6) Caffeine $0.001 \% \quad \ldots \quad \ldots \quad \quad \ldots .320$

There is here no evidence whatever that the caffeine combined with dextrose stimulates, on the contrary what little difference there is indicates retardation. The best growth took place in tapwater, followed closely by the 0.001 per cent. caffeine solution. 
Alasns. (All solutions in tap water)

Mustard 1.0 g. seed in each glass and 50 c.c. fluid. Sown on 16/12/1911. Room temperature

$$
\begin{array}{cc}
\text { Condition on } \\
19 / 12 / 1911 \\
\text { in order of merit }
\end{array}
$$

\section{Condition on}

\section{Number of not germinated 20/12/1911}

39

\section{Tap water}

$$
0.0001 \% \text { caffeine }
$$$$
0.001 \text {, caffeine }
$$

$\{0 \cdot 1$ " alanin

$\left\{\begin{array}{l}0.0001, \text { caffeine } \\ \text { " }\end{array}\right.$

0.1 , alanin

$\{.001$ " caffeine

$\begin{array}{llll}\text { Alanin 0.5 \% } & \ldots & \ldots \\ \text { Caffeine 0.0001 \% } & \ldots & \ldots\end{array}$

Alanin 0.1 \% ...

Caffeine 0.01 \% $\quad \ldots \quad \ldots$

Alanin 0.1 \% $\quad \ldots \quad \quad \ldots$

Caffeine 0.001 \% $\quad \ldots \quad \ldots$

Alanin 0.1\%

Caffeine 0.0001 \%

ङే $\left\{\begin{array}{lll}0.5 & , \text { alanin } \\ 0.0001 & , \text { caffeine }\end{array}\right.$

F्व $\left\{\begin{array}{lll}0.5 & \text { " alanin }\end{array}\right.$

( $0.001 "$ " caffeine

Caffeine 0.01 \% $\ldots . \quad \ldots$

Caffeine 0.001 \% $\quad \ldots \quad \ldots$

Caffeine 0.0001 \% ... ...

Tap water $\quad . . \quad \ldots \quad$... Worst
, alanin

, caffeine

, caffenie
" alanin
Weight, 20/12/1911

without not germinated

$2 \cdot 750$

$3 \cdot 465$

$2 \cdot 265$

$\mathbf{3 \cdot 0 5 0}$

$2 \cdot 610$

$3 \cdot 190$

34

3.550

25

$\mathbf{3} \cdot \mathbf{3 8 0}$

22

$\mathbf{3} \cdot \mathbf{8 5 0}$

24

3.850

25

$4 \cdot 355$

19

$4 \cdot 420$

The table shows that more seeds germinated and the seedlings developed best in tapwater. There were no signs of stimulation, on the contrary the combination alanin-caffeine was more deleterious than caffeine alone.

Wrtte's Peptone. (All solutions in tap water)

Mustard 1.0 g. in each glass and 50 c.c. fluid. Sown on 19/12/1911. $22^{\circ} \mathrm{C}$.

Medium

Condition on 20/12/1911

(1) Peptone $0.5 \% \quad \ldots \quad \ldots 5$ and 6 have begun to sprout

(2) Peptone 0.5\% … …

(3) Peptone $0.5 \% \quad \ldots . \quad \ldots .1,2,3,4$ have Caffeine $0.02 \% \quad \ldots \quad \ldots \quad$ hardly any

(4) Peptone $0.5 \% \quad \ldots \quad \ldots$ sprouts
Condition on 21/12/1911

6 is much the best

Then 1 and 2

Then 5

3 and 4 are the least grown
Weight on

21/12/1911 $3 \cdot 410$

$3 \cdot 280$

$2 \cdot 830$

$2 \cdot 700$

2900

4.800

(5) Tap water $\ldots$.

(6) 'lap water $0 . . . \quad \cdots$

The seeds in tapwater developed best, and the combination of peptone with caffeine was more inhibitory than either peptone or caffeine alone. 
Witte's Peptone. (All solutions in tap water)

Mustard $10 \mathrm{~g}$. in each glass and 50 c.c. fluid. Sown on 20/12/1911. $22^{\circ} \mathrm{C}$.

$\begin{array}{ccccc}\text { Medium } & \begin{array}{c}\text { Condition on } \\ 21 / 12 / 1911\end{array} & \begin{array}{c}\text { Condition on } \\ 22 / 12 / 191 \mathrm{i}\end{array} & \begin{array}{l}\text { IVeighed on } \\ 22 / 12 / 1911\end{array} & \begin{array}{c}\text { Arranged in order } \\ \text { of merit }\end{array}\end{array}$
(1) Peptone 0.1\% ... 11 and 12 have 12 is the best

(2) Peptone 0.5\% … Then 9, 10, 11

(3) Peptone 0.5\% ... Then 9 and 10 Of the rest, 1, 2, Caffeine $0.01 \%, \ldots \quad 8,7,6$ are better than $3,4,5$

(4) Peptone $0.5 \% \quad \ldots$ The rest are Caffeine $0.001 \%$... fairly equal, 5 being the least grown (5) Peptone $0.5 \%$
Caffeine $0.0001 \%$

(6) Peptone $0.1 \%$

(7) Peptone $0 \cdot 1 \%, \ldots$ Caffeine $0.001 \%$...

(8) Peptone 0.1\% ... Caffeine $0.0001 \% \cdots$

(9) Caffeine $0.01 \% \quad \ldots$

(10) Caffeine $0.001 \%$

(11) Caffeine 0.0001\% $\%$

(12) Tap water

The best results were obtained with tapwater followed closely by the weakest cafteine solution. The combination of caffeine with peptone was more inhibitory than either caffeine or peptone alone.

\section{Conclusions}

The foregoing experiments afford ample evidence that caffeine added in the proportion of from 1 per cent. to 0.01 per cent. to water, in which seeds are then sown, exercises a powerful effect in retarding germination and growth. If as much as $\mathbf{1}$ per cent. caffeine is present there may even be complete inhibition of germination.

On the other hand there is nothing at present to show that caffeine, either alone or in combination with other substances can act as a stimulant to plant life. Nevertheless, the subject is not exhausted and the investigations are being continued. 
TABLE I

Sown on $31 / 10 / 1911$, at Room temperature

$\begin{array}{cccc} & \text { Cress, } 0 \cdot 5 \mathrm{~g} \text {. in each } & \text { Radish, } 18 \text { seeds in } & \text { Mustard, 0.5 g. in } \\ \text { glass } & \text { each glass } & \text { each glass } \\ \text { Medium } & \text { Condition on } & \text { Condition on } & \text { Condition on } \\ & 3 / 11 / 1911 & 4 / 11 / 1911 & 3 / 11 / 1911\end{array}$

$\begin{array}{llll}1 \% \text { caffeine in water } & \ldots \text { None germinated } & \text { None germinated } \\ 0.1 \% \text { caffeine in water } & \ldots \text { A very few small } \\ \text { shoots } & \text { None germinated } \\ 0.01 \% \text { caffeine in water } & \ldots \text { The greater part } \\ \text { sprouted } 2 \mathrm{~mm} . & \begin{array}{c}\text { A few very small } \\ \text { shoots }\end{array} \\ 0.001 \% \text { caffeine in water } & \ldots \text { The greater part } \\ \text { sprouted } 3 \mathrm{~mm} . & \begin{array}{c}\text { The greater part } \\ \text { sprouted } 2 \mathrm{~mm} .\end{array} \\ \text { Tap water only } & \ldots & \begin{array}{c}\text { Equal. Almost all } \\ \text { sprouted } 3-4 \mathrm{~mm} .\end{array} & \begin{array}{c}\text { Equal. Mostly } \\ \text { sprouted } 3 \mathrm{~mm} .\end{array}\end{array}$

Mustard, $0 \cdot 5 \mathrm{~g}$. in each glass. Sown on Lettuce, $0 \cdot 3 \mathrm{~g}$. in each glass. Sown on

$10 / 11 / 1911$, at room temperature $25 / 11 / 1911$, at room temperature

Radish, 18 seeds in each glass. Sown on $5 / 12 / 1911$. $22^{\circ} \mathrm{C}$.

Medium

$$
\text { Condition on }
$$

Medium

Condition on
$28 / 11 / 1911$

None germinated

None germinated

A few just showing

The greater part sprouted

Equal. Almost all sprouted. 'The best grown

\begin{tabular}{|c|c|}
\hline $0.1 \%$ caffeine & $\begin{array}{l}\text { A few very small } \\
\text { shoots }\end{array}$ \\
\hline $0.02 \%$ caffeine & $\begin{array}{l}\text { Mostly sprouted, } \\
\text { but small }\end{array}$ \\
\hline $0.004 \%$ caffeine & $\begin{array}{l}\text { Mostly sprouted, } \\
\text { longer }\end{array}$ \\
\hline $0.0008 \%$ caffeine & $\begin{array}{l}\text { Mostly sprouted. } \\
\text { The best } \\
\text { grown. Equal }\end{array}$ \\
\hline
\end{tabular}

$0 \cdot 1 \%$ caffeine

None germinated

Condition on 7/12/1911

A few very small shoots

$0.01 \%$ caffeine Few and small

More and stronger

$0.001 \%$ caffeine More and larger

More still and stronger

About equal. Distinctly the best grown

About equal. The best grown
Tap wator only )

\section{Table II}

Mustard, $0.5 \mathrm{~g}$. in each glass. Sown on 31/10/1911. Room Temperature

Radish, 18 seeds in each glass. Sown on 5/12/1911.

Room temperature

Condition of seeds on

Medium

Number not germinated

$1 \%$ caffeine

$0.1 \%$ caffeine

$\begin{array}{ll}\ldots & 103=\text { all sown } \\ \ldots & 35\end{array}$

$0.01 \%$ caffeine

$\begin{array}{ll}\cdots & 35 \\ \cdots & 26\end{array}$

$0.001 \%$ caffeine

$0.0001 \%$ caffeine $\quad \ldots . \quad 17$

Tap water

... 16 $12 / 12 / 1911$

$$
\stackrel{\text { Not }}{\text { germinated }}
$$

Radish, 18 seeds in each glass. Sown on 5/12/1911. $22^{\circ} \mathrm{C}$.

Condition of seeds on $12 / 12 / 1911$

Germinated

Not germinated

$\begin{array}{rrr}5 & 13 & 8 \\ 7 & 11 & 10 \\ 6 & 12 & 10 \\ 12 & 6 & 13 \\ 14 & 4 & 13 \\ 13 & 5 & 14\end{array}$




\section{THE ACTION OF CAFFEINE UPON SEEDS}

TABLE III

Mustard seed, $1 \cdot 0 \mathrm{~g}$. in each glass. Sown on $17 / 12 / 1911.22^{\circ} \mathrm{C}$.

Medium

$\begin{array}{lllll}0.001 \% \text { caffeine } \ldots & \ldots & \ldots & 4 \cdot 520 \mathrm{~g} . \\ 0.0001 \% \text { caffeine } \ldots & \ldots & \ldots & 4 \cdot 750 \\ 0.00001 \% \text { caffeine } & \ldots & \ldots & 4 \cdot 610 \\ 0.000001 \% \text { caffeine } & \ldots & \ldots & 4.770 \\ \text { Tap water } \ldots & \ldots & \ldots & \ldots & 4 \cdot 830 \\ \text { Tap water } \ldots & \ldots & \ldots & \ldots & 4.710\end{array}$

TABLE IV

Turnip seed, $0.5 \mathrm{~g}$. in each glass. Sown on $15 / 11 / 1911$. Room temperature

\section{Medium}

$0.1 \%$ caffeine $0.02 \%$ caffeine $0.004 \%$ caffeine $0.0008 \%$ caffeine $0.00016 \%$ caffeine

Tap water
Weight on 22/11/1911

$\begin{array}{lll}\ldots & \cdots & 2 \cdot 400 \mathrm{~g} . \\ \ldots & \cdots & 3 \cdot 070 \\ \ldots & \cdots & 3 \cdot 530 \\ \ldots & \cdots & 3 \cdot 760 \\ \ldots & \cdots & 3 \cdot 740 \\ \ldots & \cdots & 3 \cdot 730\end{array}$

Cress, 0.5 g. in each glass. Sown on 15/11/1911. Room temperature

$$
\text { Weight on 22/11/1911 }
$$
$2 \cdot 530 \mathrm{~g}$.
$3 \cdot 830$
$4 \cdot 320$
$5 \cdot 370$
$6 \cdot 320$
$6 \cdot 430$ 